\title{
Project Earthrise: Inspiring Creativity, Kindness and Imagination in Planetary Health
}

\author{
Alan C. Logan ${ }^{1}$, Susan H. Berman ${ }^{1,2}$, Brian M. Berman ${ }^{1,2,3}$ and Susan L. Prescott 1,2,4,*(D) \\ 1 inVIVO Planetary Health, The Worldwide Universities Network (WUN), Baltimore, MD 21231, USA; \\ alanxlogan@gmail.com (A.C.L.); sberman@tiih.org (S.H.B.); bberman@tiih.org (B.M.B.) \\ 2 The Institute of Integrative Health, Baltimore, 1407 Fleet St, Baltimore, MD 21231, USA \\ 3 Center for Integrative Medicine, Department of Family and Community Medicine, \\ University of Maryland School of Medicine, Baltimore, MD 21201, USA \\ 4 The ORIGINS Project, Telethon Kids Institute and University of Western Australia, \\ Perth Children's Hospital, 15 Hospital Avenue, Nedlands, WA 6009, Australia \\ * Correspondence: Susan.Prescott@telethonkids.org.au
}

Received: 1 July 2020; Accepted: 1 September 2020; Published: 4 September 2020

\begin{abstract}
The concept of planetary health blurs the artificial lines between health at scales of person, place and planet. At the same time, it emphasizes the integration of biological, psychological, social and cultural aspects of health in the modern environment. Our grandest challenges in the Anthropocene ultimately stem from human attitudes to each other and to our environment. However, solutions rarely confront the underlying value systems that created these interconnected problems, or the attitudes that perpetuate them. Too often, the dominant focus is on the "worst of human nature", and devalues or neglects the importance of empathy, kindness, hope, love, creativity and mutual respect-the deeper values that unite, empower and refocus priorities of individuals and groups. Here, we call to normalize more creative, mutualistic approaches-including the perspectives of traditional and indigenous cultures-to positively influence normative value systems. We revisit the power of inspiration with the profound example of the Apollo 8 Earthrise photo which galvanized a fledgling planetary health movement over 50 years ago. Through the inaugural Earth Day that followed, we are reminded that its early organizers were not constrained in how they defined the "environment". They and their primary speakers were as concerned about value systems as they were about pollution - that we cannot hope to solve our problems without addressing the attitudes that created them in the first place. We explore the ways in which the awe of Earthrise-and the contemporary science of creativity and studies of utopian thinking - might reinvigorate imagination, kindness and mutualism. We revisit the fundamental challenge offered by Pulitzer-Prize-winning microbiologist Rene Dubos and others in the afterglow of the Earthrise photo, and the inaugural Earth Day. This is a question of imagination: What kind of world we want to live in?
\end{abstract}

Keywords: planetary health; Earthrise; Earth Day; social justice; environmental justice; imagination; hope; creativity; nature; Anthropocene; climate change; utopian thinking; biodiversity; NCDs (non-communicable disease); DOHaD (developmental origins of health and disease); cross-sectoral initiatives

\section{Introduction}

"Look at that picture over there! Here's the Earth comin' up. Wow is that pretty! Hand me that roll of color, quick, would you? Just grab me a color. Hurry up. Got one?"

Apollo 8 Astronaut William Anders, moments before taking one of the most famous photos in human history. 
The photograph, known as "Earthrise", taken by astronaut Bill Anders on the Apollo 8 mission of 1968, became one of the most significant images of the 20th Century. To see the fragile beauty of planet Earth, a blue jewel in the vastness of space, was a transcendent moment in modern history. It gave a new and very significant perspective- "We came all the way to the moon to discover Earth", Anders reflected on a moment that really shifted collective consciousness [1].

Through the filter of North American media at the time, it was obvious what was "seen". We saw our home. We saw one planet for all people. We saw the fragility of the thin surface of life enfolding the planet. Dynamic and wondrous in its beauty. A miracle. This triggered a profound shift in both environmental awareness and the potential for human unity. When we look at our home from this perspective, it seems utterly illogical that we are gorging the Earth for resources that are spent in large part on developing weaponry and destruction. This was a threshold event for both human progress and human awareness-a foundational inspiration for change on many levels.

Perhaps we should all take a look at that photograph from time to time. The feelings of awe and wonder, kindness and unity, are arguably what we need most as we face the greatest challenges of our time.

The grand challenges of the Anthropocene are many, and mostly of our making-ultimately stemming from human attitudes to each other and to our environment-war and destruction, poverty and inequality, chronic disease and despair and the destruction of ecosystems on all scales, including those we depend on. This also extends to the creation of the many systems that perpetuate these problems.

The solutions must also be of our making and recognize the interdependent nature of our challenges. But we cannot hope to solve our problems without addressing the attitudes that created them in the first place.

Concepts of planetary health recognize these interwoven complexities-the interdependent vitality of all natural and anthropogenic ecosystems (social, political and otherwise [2]), that the health of human civilization is bound to the health of natural systems [3], and blurs the artificial lines between health at scales of person, place and planet. Rather, it emphasizes the integration of biological, psychological, social and cultural aspects of health in the modern environment, and the need to address these collectively across every level [4].

However, this rarely confronts the underlying value systems that created these problems, or the attitudes that perpetuate them. If anything, the focus is usually on the "worst of human nature" which is only likely to perpetuate despair and hopelessness. The focus is often on the separate "symptoms" and "signs" of "disease" and trying to tackle them individually-the aspects of environmental damage, biodiversity loss, climate change and ecological imbalances giving rise to pestilence and contagions, chronic lifestyle diseases, poverty and famine, social unrest, rioting and agitation-rather than the compass that set this course. The planetary health agenda must therefore equally consider our social and spiritual ecology as it does the ecology of natural systems, as these drive the value systems that create and perpetuate many of our global challenges in the first place.

The "best of human nature" is frequently overlooked or ignored. We have devalued the power of empathy, kindness, love and mutual respect-the very things that unite and empower people and refocus priorities of individuals and groups. In doing so we have failed to recognize that this is both part of the problem in the first place, and that these are arguably our greatest assets in overcoming our biggest challenges.

The purpose of this Viewpoint is to emphasize the need to normalize more creative, mutualistic approaches-including the perspectives of traditional and indigenous cultures-and to positively influence normative value systems.

Indeed, the early origins of the contemporary planetary health concept actually encompassed these philosophies and can be traced to distinct, but overlapping movements-environmentalism, holistic/lifestyle medicine and public health with the planet in mind [5-7]. As explored below, historians and scholars have often concluded that NASA's multi-billion-dollar Apollo Program was at least 
one major catalyst for the acceleration and coalescing of these movements-a project that was itself based on human imagination [8,9]. At first glance the relationship between a highly technical "hard" science enterprise like the Apollo program and so-called "fuzzy" science of nature relatedness, positive emotions and holism in health might seem bizarre, but the singular NASA "Earthrise" photograph provides the link (Figure 1). As NASA's Director of Photography for the Apollo Program would say three decades after the photo was taken, "it all ended up that nineteen cents worth of film became the most important part of a multi-billion dollar project" [10].

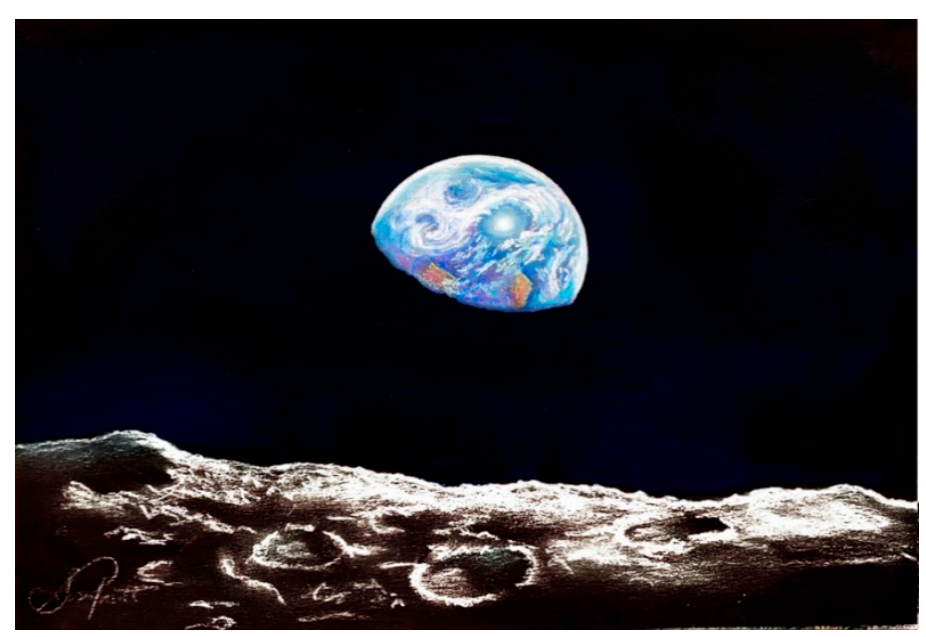

Figure 1. Earthrise. Inspired by the photograph taken by Apollo 8 Astronaut William Anders; one of the most influential images in human history. Artwork by SLP.

\section{Roadmap to the Viewpoint}

Here in our Viewpoint article, we start by briefly revisiting the ways in which the inspiration of the Earthrise photo galvanized a fledgling planetary health movement. Included in this history is the inaugural Earth Day, and a reminder that its early organizers were not constrained in how they defined the "environment". They and primary speakers were as much (if not more) concerned with broad socioeconomic injustices and the deeper value systems underpinning Earth's many challenges, than they were about pollution specifically.

The aim of this brief sortie into Earthrise-Earth Day history is to provide context for an exploration of the ways in which the awe of Earthrise-and the contemporary science of creativity and studies of utopian thinking - might reinvigorate imagination within the larger planetary health network. The 2015 Lancet Commission on Planetary Health specifically identified the great need to address the failure of empathy and "imagination challenges" in addition to knowledge failures ("information challenges") and implementation failures ("governance challenges") [3]. The example given was our over-reliance on gross domestic product as a measure of human progress. However, at least one leader within the contemporary planetary health movement, Lancet Editor-in-Chief Richard Horton, expressed concern that planetary health might slip into a cubbyhole as a retooled environmental health discipline, rather than its true enterprise, which in his words is "an inquiry into our total world. The unity of life and the forces that shape those lives". He opined recently that planetary health is "a capacious interdisciplinary inquiry [that] is neither capacious nor interdisciplinary enough" [11].

We agree with this sentiment and argue that the contemporary planetary health movement, now that it is gelling into its own interdisciplinary "discipline" of sorts, would do well to go back to the fundamental question asked by Pulitzer-Prize-winning microbiologist Rene Dubos and others in the afterglow of the Earthrise photo and the inaugural Earth Day. This is a question of imagination. In the words of Dubos: 
"Now that scientific technology has made us so powerful, and so destructive, we must try to imagine the kinds of surroundings and ways of life we desire, lest we end up with a jumble of technologies and counter-technologies that will eventually smother body and soul."

Rene Dubos, Man Overadapting, 1971 [12]

Thus, we will briefly examine the science of imagination and creativity to the extent that it might maximize the reach of planetary health through broad inclusion, and provide diverse viewpoints aimed at identifying the kind of world we want to live in. In doing so, we seek to place a higher value on creativity, imagination and self-development in solving challenges at all scales. We also emphasize the importance of cultural expression, artistic creations and narrative work in linking the health of people, place and planet. This will place more value on the power of positive emotional assets in health and resilience on all scales (awe, wonder, joy, love, compassion)—recognizing that these also mediate environmental concern and social responsibility. Finally, this leads toward the study of utopian thinking, an area which scholars have recently applied to the construct of planetary health [13]. We expand on this and conclude with a planetary health hypothesis of our own. That is, when imagining a better society beyond the current state of affairs - the essence of utopian thinking - there is likely to be large-scale solidarity and consistency in what that might look like. In an increasingly polarized world [14], finding common ground would seem like a good place for planetary health to find its roots, especially as we seek to inspire those who will inherit the future (Figure 2).

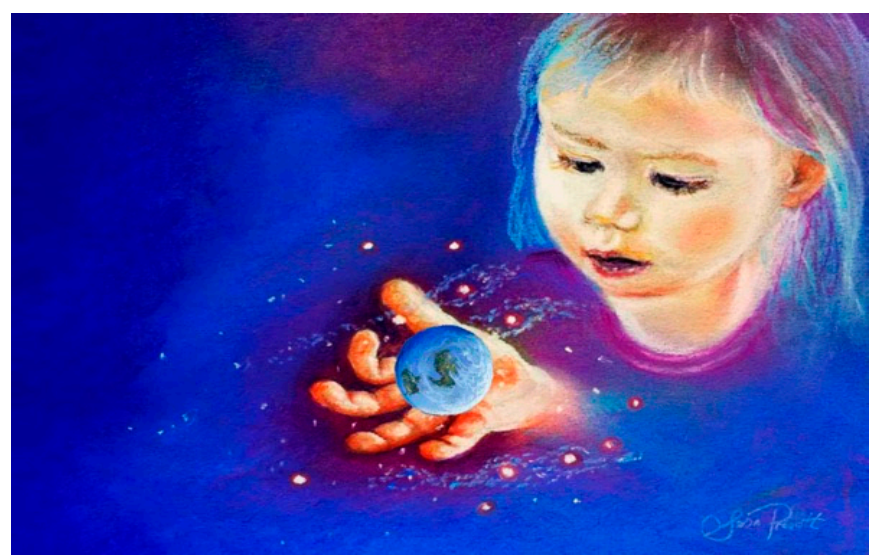

Figure 2. Planetary health depends on inspiration and imagination. Solutions will depend on the engagement that comes from unity and purpose, and the sense of awe and wonder inspired by nature. Artwork by SLP.

\section{Earthrise, Earth Day}

"A remarkable effect of the Apollo 8 Moon voyage was not so much its capacity to draw [humanity's] gaze outward as its powerful force in turning their thoughts inward on their own condition and that of their troubled planet...the flight of the astronauts produced great mental and spiritual ferment among [humans on Earth]"

Robert J. Donovan, Washington Bureau Chief, Los Angeles Times, 1968 [15]

On 24 December 1968, Apollo 8 astronaut William Anders took what has been described as the "mightiest shot in the Cold War [that] turned into the twentieth century's ultimate utopian moment" [8]. The shot, in this case, was a color photograph [16] that became known, almost instantaneously, as "Earthrise". Although it was not the first color photograph of the Earth from space, the distinction was the presence of the gray lunar surface in the foreground (Figure 1). As biologist Lewis Thomas described it, the dry dusty Moon was "as dead as an old bone", compared to the rising Earth, "exuberant " in its colors [17]. Anders was fully appreciative of the transformative implications of the Earthrise 
photo-_"We came all this way to explore the Moon, and the most important thing is that we discovered the Earth", he said [18].

"I happened to glance out of one of the still clear windows just at the moment the Earth appeared over the lunar horizon. It was the most beautiful, heart-catching sight of my life, one that sent a torrent of nostalgia, of sheer homesickness, surging through me. It was the only thing in space that had any color to it." [19]

\section{Frank Borman. Apollo 8 Astronaut.}

The contrasting lifelessness of the Moon was obvious; no matter how hard sci-fi writers and space pitch-men like Isaac Asimov and Arthur C. Clarke tried to sell the idea that lifeless Moon rocks "From the lunar surface may tell us more about man and his environment than we could ever hope to learn right here on Earth" (Asimov [20]) and a scientific "bonanza of more value than all the gold mines ever found" (Clarke [21]), the public seemed captivated by the living portion of the Earthrise photo. In time, microbiome science would show us that a single grain of Earthly sand (Figure 3), teeming with up to 100,000 microbes [22], could tell us much more about the interconnected web of life, including humans and their biodiverse environment [23], than anything on the Moon. The inherent value of Moon rocks brought back to Earth seems to be held in their ability to provoke awe [24].

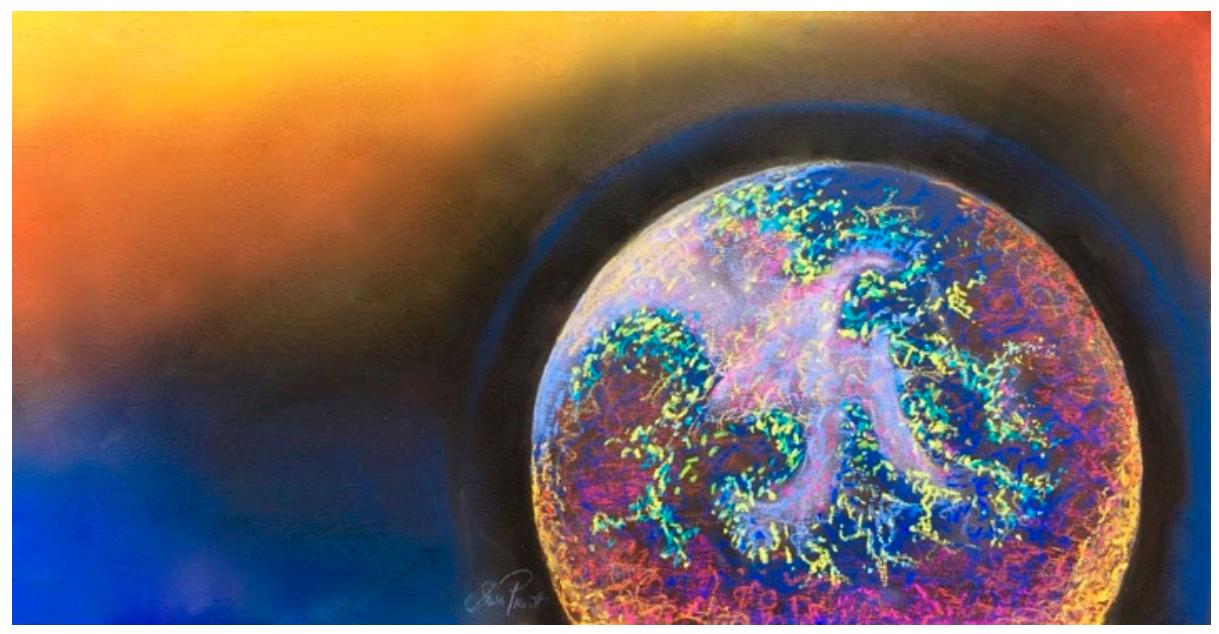

Figure 3. New worlds discovered, teaming with life where we never expected it. More than 100,000 life forms were discovered on a single grain of sand from the North Sea-with complex carbon, nitrogen and sulfur cycles for nutrient production and filter systems. Artwork by S.L.P, inspired by micrographic photography by Probandt, et al. [22].

Given the widespread dissemination in the popular press in the first half of 1969, there is little disagreement among historians and interdisciplinary scholars that the Earthrise photo was at the very least a catalyst in galvanizing the environmental movement within the United States (US), an image that helped bring the word ecology into popular culture $[8,9,25]$. The emotional reactions to the Earthrise photo, at least in the US [26], seemed to assure a collective response. It was an image that quickly embedded itself in the human consciousness. Imagination was stirred. The Whole Earth Catalog, a successful counterculture magazine, placed Earthrise on its cover in 1969, and in the issues following Earth Day, concluded that "Earthrise established our planetary facthood and beauty and rareness (vs. dry moon, barren space) and began to bend human consciousness" [27].

Based on contemporary neuroscience studies involving the induction of awe (wherein breathtaking nature scenes, or indeed, images of the Earth from space, can invoke awe [28,29]), there seems little doubt that Earthrise, the first widely-distributed color photograph of Earth from space, induced awe, and on a larger scale, a collective sense of the sublime. Neuroimaging studies inform us that the induction 
of awe activates the areas of the brain associated with imagination [28]. Induction of awe directs attention toward the external environment, increases feelings of oneness to other (unknown) humans, increases willingness to volunteer, increases subsequent desire to spend time in creative pursuits, decreases materialism and increases connectedness to nature and pro-ecological behavior [30-32]. Importantly, awe induction through dramatic Earth-from-space videos has been shown to promote humility (an approach to life that minimizes ego and values accurate self-awareness [33]) which, in turn is linked to enhanced social relationship qualities and reduced arrogance, entitlement and narcissism [34].

We can only speculate on the ways in which the contemporary research on awe applies to the events that are now five decades in the past, or the extent to which Earthrise induced awe, and spiked emotions to contribute to social movements in the US. What we do know is that just sixteen months after Earthrise, the first Earth Day brought thousands of North Americans into the streets and lecture halls, which in turn sparked multinational Earth Day events in the years that followed [35]. While the inaugural Earth Day is now often viewed as mostly an anti-pollution and anti-environmental toxin crusade, the organizers and primary speakers at the time did not see it that way. On this score there is no speculation. In the months following Earth Day, the organizers published their own talks along with those of more than fifty of the primary speakers. We share their often-forgotten voices here to make this important point:

Senator Gaylord Nelson, widely attributed as the founder of the inaugural Earth Day, said "our goal is an environment of decency, quality, and mutual respect for all other human creatures and for all other living creatures. An environment without ugliness, without ghettos, without discrimination, without hunger, without poverty, and without war". His colleague, Senator Walter Mondale, added that "the crisis of environmental decay is clearly bound to the crises of poverty, blight, racism, war, and economic injustices. The [current] 'environment' is a culture that seems to value quantity over quality; self-interest, convenience and expediency above the beauty and mystery of nature"[36].

National Earth Day coordinator Denis Hayes said on the day that "what we are trying to do is an affirmation of life. We have to change people's values" [37]. He pointed out that "we're spending insanely large sums on military hardware instead of eliminating hunger and poverty. We squander our resources on moon dust while people live in wretched housing. We still waste lives and money on a war that we should never have entered and should get out of immediately" [36]. His colleague Barbara Reid, also leading the Earth Day coordination, echoed the sentiment: "Pollution is not our only problem. We must not succumb to those who hope that concern with the environment will turn us away from Vietnam or civil rights. Pure water will not wash away the stain of an immoral war. Clean air will not dispel the odor of a society that tells only the poorest among us to ask what they can do for their country"[36].

In his Earth Day address, noted civil rights leader Channing E. Phillips said "I'm here tonight not because we're changing issues in the middle of the stream, but out of a deep conviction that racial injustice, war, urban blight and environmental [abuse] have a common denominator in our exploitive economic system. And that as you pursue your legitimate concern with pollution of our environment, you will discover that our basic problem is pollution of the mind-a value system that uses the profit motive not as fuel which moves us along, but as a compass that determines our direction" [36].

Writing in the New York Times in July 1969, novelist and social commentator Kurt Vonnegut, Jr., eluded to Earthrise. He wrote that the "Earth is such a pretty blue and pink and white pearl in the pictures NASA sent me. It looks so clean. You can't see the all the hungry, angry earthlings down there-and the smoke and the sewage and trash and sophisticated weaponry" [38]. That became an oft-repeated pull quote, but Vonnegut's sentences immediately following the quote describe the socioeconomic realities central to the Earth Day mission: "I flew over Appalachia the other day-about 500 miles an hour and five miles up. Life is said to be horrible down there in many places, but it looked like the Garden of Eden to me. I was a rich guy, way up in the sky, munching dry-roasted peanuts and sipping gin" [38]. 
Even the Apollo 8 astronauts, who may not have anticipated entering such philosophical discussion when they first left orbit (Figure 4), soon echoed the public sentiment. "The moon was so desolate, so uninviting...the view of the Earth from the moon fascinated me. It was hard to think that that little thing [visible Earth] held so many problems. Raging nationalistic interests, famines, wars, pestilence don't show from that distance", said Frank Borman [39].
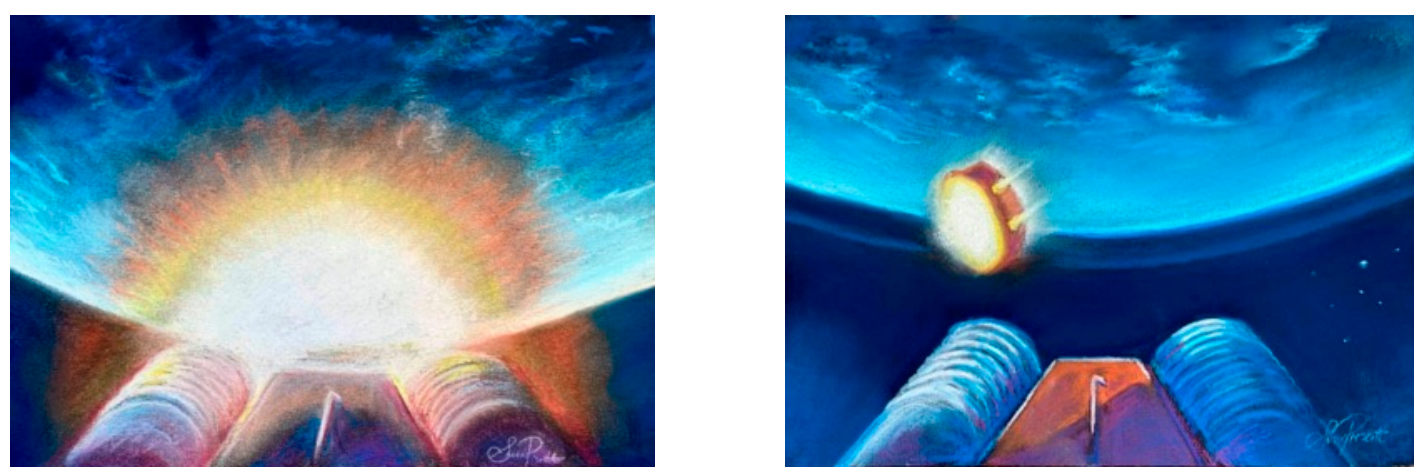

Figure 4. Leaving the problems of the Earth behind. As the Apollo 8 mission blasted through the Earth's atmosphere, it held dreams of new frontiers not unlike visions of 'terraforming' Mars today. In the multibillion-dollar search for new worlds, none anticipated that history would soon be changed by nineteen cents worth of film and an unscheduled photograph of Earth, inspiring how we might better live on our own planet. Art by S.L.P inspired by video footage transmitted from the 1968 Apollo 8. mission.

As Earth Day celebrates its 50th anniversary, there is no question that many aspects of the total environment have improved dramatically since its inaugural 'march' forward. Clean Air and Clean Water acts have been passed. There is much to celebrate. However, as described below, it is also easy to argue that many interrelated problems are even more pressing today-particularly the less publicized aims of the Earth Day organizers. By its 20th anniversary, in 1990, Earth Day had become an exercise in consumerism, an opportunity to introduce unlimited product "choices" and new flavors of soy ice-cream; Time magazine called Earth Day 1990 a "commercial mugging", a fanfare that appeals "to the abbreviated American attention span with a huge 24-h dose of stunts, palaver and celebrity hoo-ha" [40]. Therein lies the rub. Scholars have pointed out that there has been a proliferation of choices that represent no real choice, "we have become mere consumer citizens, furiously making choices at the micro-level, signifying nothing" [41].

Forty years after the Earthrise photo, Apollo 8 astronaut James Lovell summed up the initial exuberance and the resultant return to an unacceptable normalcy: "We didn't know the impact of the flight on people of the world until we got back...[at the time] people felt that the space program put human problems in perspective and that humanity would change as a result. But the mind forgets very easily, and not too long after that people got back to the way they lived before-wars and disruption and human cruelty" [42].

\section{Anthropocene Syndrome-Race for the Cure}

The term "Anthropocene Syndrome" has been used to describe the wicked, interrelated challenges of our time. These include, but are not limited to, grotesque biodiversity losses, climate change, environmental degradation, resource depletion, global burden of non-communicable diseases (NCDs), health inequalities, social injustices, the spread of ultra-processed foods, over-consumption and incivility [43].

Virtually all of the symptoms of Anthropocene Syndrome-its grand challenges-are held in place by a neoliberal ideology that ignores the underlying systems of causation $[44,45]$. The current coronavirus (COVID-19) pandemic is unmasking disadvantage and precariousness; the early bumper-sticker slogan "COVID does not discriminate" turns out to be a dangerous 
myth [46]; individuals with pre-existing NCDs (the burden of global NCDs are shouldered by the disadvantaged [47]) are more susceptible to severe illness and mortality [48-50] (Figure 5).

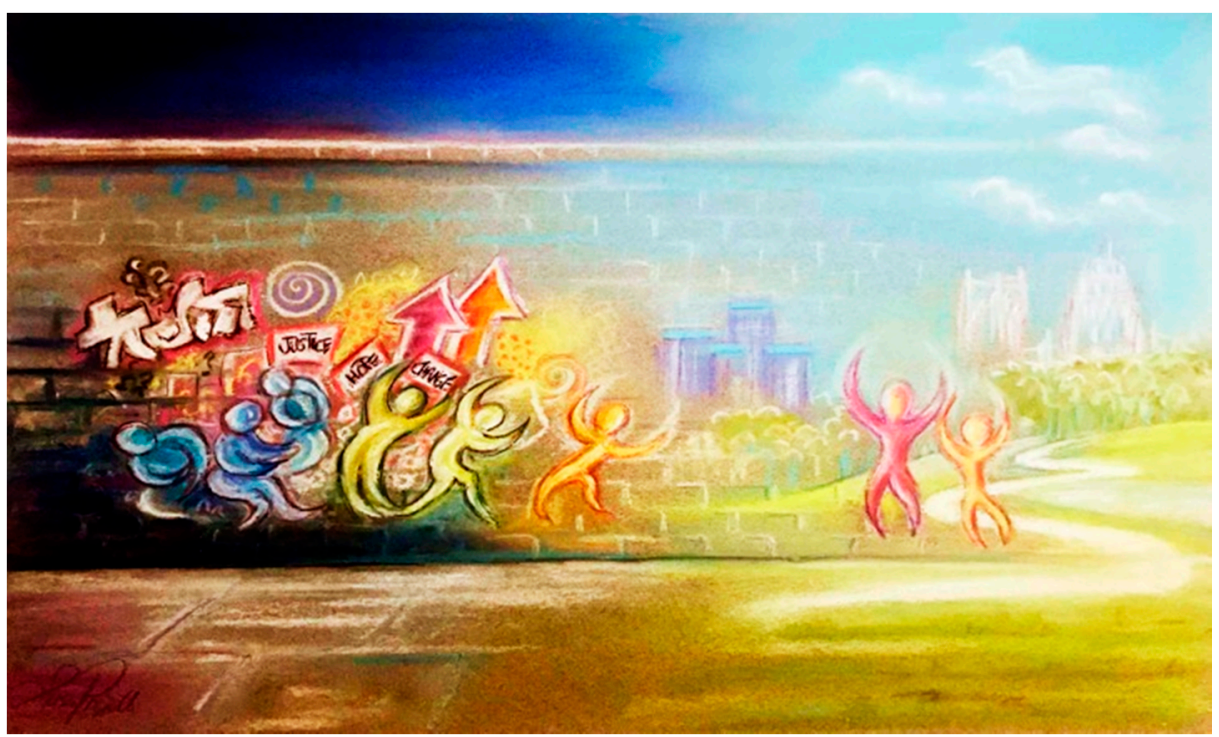

Figure 5. The unequal burden of the Anthropocene. The personal, social and economic challenges of the Anthropocene are shouldered disproportionately by those who have the least resources to cope with adversity. Achieving planetary health requires addressing inequities and recognising that the resiliency at all scales is dependent upon equity and diversity. Art by S.L.P.

The urgency of interconnected challenges has accelerated interest in the concept of planetary health. The term planetary health-denoting the interconnections between the health of person and place at all scales-emerged from the environmental and holistic health movements of the 1970-1980s [5]. Four decades ago, the well-known environmental advocacy group Friends of the Earth expanded upon the World Health Organization (WHO) definition of health to include healthy ecosystems: "health is a state of complete physical, mental, social and ecological well-being and not merely the absence of disease-personal health involves planetary health" [51]. More recently, planetary health has been defined as the interdependent vitality of all natural and anthropogenic ecosystems (social, political and otherwise [2]) - and affirms that the health of human civilization is intricately connected to the health of natural systems within the Earth's biosphere [3].

\section{Imagination, Creativity and Innovation}

"I tried to put myself in the place of the virus, and the immune system, and see how they would behave and why," Jonas Salk, on using his imagination to discover the polio vaccine [52].

Before discussing the contemporary study of utopian thinking-at its core the stirring of the imagination-a brief sortie into the research surrounding imagination and creativity can illustrate their potential value to planetary health. Imagination refers to the process whereby individuals "disengage" from the immediate realities of the social and material environment and engage in the formation of novel ideas, or images or concepts of external objects not immediately present to the senses. Imagination allows individuals or groups to rally around goals by exploring the past, future, and alternative possibilities [53]; creativity at its most basic level refers to the development or recognition of ideas, alternatives or possibilities- the ability to make contributions that are novel and task appropriate. The fruits of creativity, especially when they surprising to others, may be useful in solving problems, assisting in communicating with others, and may possess broad social value [54-56] (Figure 6). Indeed, the trajectories of notable social movements, those involving civil rights or social justice for example, can be tied to imagination and creativity [57,58]. Recall, Martin Luther King's galvanizing oration, certainly one of the most famous speeches in human history, which involved "having a dream" [59]. 


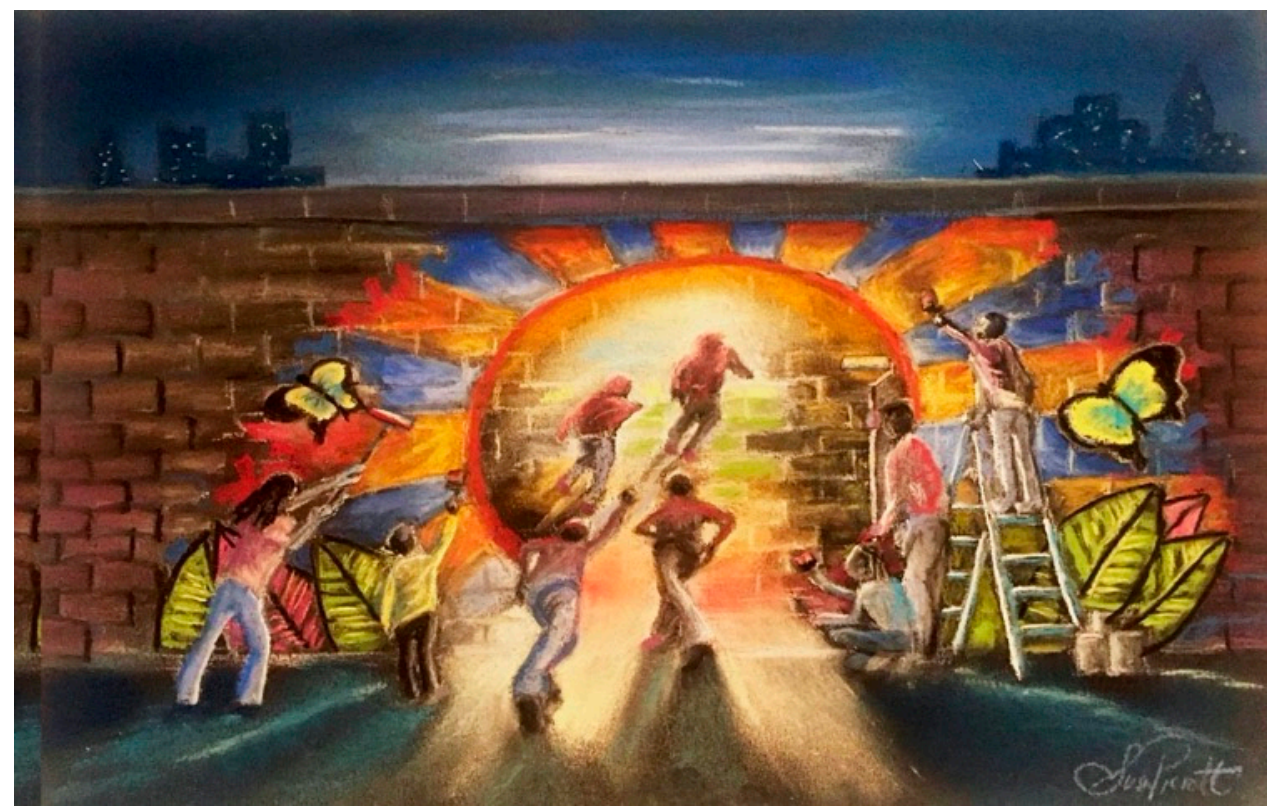

Figure 6. Imagining a better future. Creativity can inspire hope and optimism to create new possibilities, opportunities and the power of shared purpose. Art by S.L.P.

In our era of high technology, innovation is defined as the "successful implementation of creative ideas" [60]. Compare that to dictionaries at the turn of the 20th century, which defined innovation in this way: the introduction of new things or methods; something new introduced into established arrangements of any kind. Interestingly, after providing the aforementioned definition, one of the leading dictionaries in the early 1900s noted that "innovation is not necessarily improvement" [61]. The long arc of history underscores the saliency of that peculiar dictionary note-there is little doubt that innovation "created" the Anthropocene and its associated Syndrome! In the post-Earthrise era, the word innovation is presumed to be a "good", oft-attached to ideas associated with high technology or a so-called disruptive platform; the "black box warning" that innovation is not necessarily improvement seems absent.

Select scientists have written extensively about the need for imagination in our efforts to address climate change. Mike Hulme writes that rather than asking "How can we solve climate change?" we should be asking the question "How does the idea of climate change alter the way we arrive at and achieve our personal aspirations and our collective social goals?" The difference is magnificent. Hulme argues that the idea of climate change (as opposed to the techno-fixes directed only at the physical aspects) opens the door to imagination, in his words "to inspire new artistic creations in visual, written and dramatized media"[62].

We could not agree more. However, within the academic lexicon, the preferred word is "innovation". Even a cursory glance at PubMed provides a tale of two words. Typing the words "climate change" and "innovation" into the PubMed search box brings the reader to over 1400 results, most of them recently published. In contrast, if keeping "climate change" but replacing the word "innovation" with "imagination" in the search box, the results differ, revealing a single-digit total of 9 articles; "creativity" paired with "climate change" provides only 24 results. Since imagination and creativity are largely precursors to innovation, we suspect that academia writ large holds anxiety surrounding use of the words "imagination" and "creativity".

We have two primary reasons for making such a claim. First, despite volumes of research proving otherwise, the science and saliency of imagination and creativity are oft-dismissed in academic circles as "soft, fuzzy or fluffy" constructs [63]. Second, while much has been written about the subject of "math anxiety" in academic settings, evidence indicates that 'creativity anxiety' is no less problematic [64].

The enduring myth that creativity is a soft science, and other myths like it, such as "people are born creative with little capacity for enhancement", only serve to interfere with furtherance 
of the study of creativity and its potential value in the post-Earthrise era. Given the undeniable success of transformative ideas, especially those that have become the driving force of (positive) social movements, there is an urgent need to study the dynamics of creativity (imagination) as a catalyst to social change [57], and thus, planetary health.

As for creativity anxiety, recent work with the validated Creativity Anxiety Scale (CAS) demonstrates that creativity-specific anxiety predicts individual differences in creative achievement and attitudes toward creativity. This emerging research has profound implications for educational institutions, especially since imagination exercises have been demonstrated to enhance science learning [65]; given the ability of mindfulness training-conscious awareness resulting from living in the moment-to lower anxiety and promote creative problem solving (at both individual level and within groups $[66,67])$, it raises the question of whether or not the upstream drivers/inhibitors of creativity are adequately addressed. However, it also has relevance to a planetary health movement highly dependent upon imaginative solutions to grand challenges. It is likely that individuals who are anxious about being creative—scoring high on CAS, yet, with tremendous potential—are currently excluded from the "marketplace" of ideas.

In addition to understanding the ways in which creativity anxiety might deplete the resource pool of viable planetary health solutions, it is also important to examine the ways in which positive emotions facilitate creative solutions [68]. What are the factors that might bridge creative potential and creative achievement? Researchers have found that emotional intelligence may be a primary mediator of creativity [69]; since emotional intelligence is also a mediator of hope and optimism [70], the path to planetary health solutions may also run through greater knowledge of the early development and facilitators of emotional intelligence. Moreover, since preliminary research has linked higher emotional intelligence and nature relatedness [71] — the latter being the extent to which an individual is drawn to, has awareness of, and fascination with, the natural world-there is room to explore research pathways. For example, nature relatedness is positively associated with cognitive and affective empathy, and inversely associated with callous and uncaring facets of personality [72]; thus, we might examine how empathy toward all wildlife (including rapidly disappearing invertebrates) is cultivated [73]; interdisciplinary teams can examine how personal connections with nature might influence the creative ideas that otherwise promote planetary health. Researchers have already shown that a 4-day immersion in natural environments can increase scores on the Remote Associates Test, a validated instrument measuring creative thinking and insight problem-solving [74].

Jonas Salk, who by his own admission used his imagination to develop a transformative polio vaccine, was acutely aware of the restrictive nature of scientific academia and associated institutions. He argued that biological scientists were isolating themselves from the imaginations of scholars in the humanities, social sciences and arts. When he started the Salk Institute he urged collaboration because "man's most persistent and difficult biological problem will not be his physical diseases, certainly not as in the past, but his relationship to himself and his fellow man" [75]. Salk urged interdisciplinary alliances to help biologists ask the right questions in their research pursuits: "It's the questions that we need to discover, because the answers preexist. If we ask the right questions, the answers will come" [76]. We argue that creative input from diverse thinkers will allow experts within planetary health to ask the right questions.

To that end, we return to Dr. Horton's concerns about planetary health being neither roomy or interdisciplinary enough. Since the conversion of creativity into realized innovation is heavily influenced by socio-political processes [77], which is to say that it is not uncommon for small groups of powerful individuals to decide upon ideas worthy of transmission, the odds of creativity anxiety among out-groups or the marginalized looms large. In other words, organizational/sociopolitical power at a certain point in the channel is immense-deciding which ideas are even allowed to challenge the existing power structures [78]! Since certain creative ideas threaten status, position and power structures, it is easy to see how resistance to ideas can be commonplace [79]. Indeed, while the word innovation is oft-used in the context of our grand challenges, discourse concerning the central cog in 
the wheel of Anthropocene Syndrome- the power dynamics of neoliberalism and its attendant social dominance orientation—is oft-elided [80].

"We have today the knowledge and the tools to look at the whole earth, to look at everybody on it, to look at its resources, to look at the state of our technology, and to begin to deal with the whole problem. I think that the tenderness that lies in seeing the Earth as small and lonely and blue is probably one of the most valuable things that we have now".

Margaret Mead, anthropologist, Earth Day, 1970 [36]

Fostering imagination within planetary health is not an "invitation only" event. Rather, it is an open casting call in which those with diverse backgrounds-socioeconomic, academic, educational, experiential and otherwise. In particular, we have much to learn from the deep traditional knowledge and scientific thought of Indigenous peoples, whose diverse notions of resilience span millennia and are grounded in culturally distinctive concepts that bridge person, community, and the environment [81]. All should be welcomed to read from their own script of creativity. Moreover, we argue that rather than challenging such diverse thinkers with constrained questions such as "how would you mitigate climate change?" or "what would you do to prevent socioeconomic inequalities?", we should return to the inaugural Earth Day quest and ask them to imagine the kind of world they want to live in.

Already, there are many imaginative "out-of-the-box" ideas that might promote health at scales of person, place and planet. For example, the relatively simple "greening" of vacant lots and urban blighted land can improve real and perceived safety among community residents, as well as better mental health $[82,83]$. In turn, this research has sparked the imagination of researchers working along the lines of microbial ecology, wherein transformation of urban blight could serve as a mechanism to increase urban exposure to biodiversity, including unseen beneficial microbes; biodiversity could introduce microbiota species or functional diversity to improve immune training and regulation in urban populations [84]. We can also look to research that shows that the pathway to healthy dietary patterns among adolescents (diets that favor health of person, place and planet) may be found in transforming the food retail environment and educating on the power dynamics associated with the marketing and sales of unhealthy products in disadvantaged communities, rather than banal informational sessions on a dietetics pyramid or academic guidelines [85-87].

\section{Utopian Thinking-What It Is, and What It Is Not}

"In the literature of social thought a numerous, but much neglected and ridiculed section consists of the so-called social utopias...they breathe a spirit and offer suggestions... utopianism is not expressed in vain; sooner or later in some form, it becomes fact. Nothing is wholly lost".

Joyce O. Hertzler, PhD. The History of Utopian Thought. 1923

In the realm of psychology, utopia is a "symbolically constructed representation of an ideal human world"; the word "world" can be taken to mean environment, and the words "symbolically constructed" underscore that utopia does not currently exist-rather, it is imagined using various forms of communication, including written word, oration, photographs and artwork [88].

The derogatory or pejorative use of the word utopia (or utopian) has often been directed at those who have fought for social change; for example, in the 1800s, physicians advocating for removing restraint policies and improving the "impossible" conditions in mental asylums were dismissed as "utopians"[89]. In 1847, anti-restraint physician reformer John Conolly described the zeitgeist: "The upholders of the old system received the announcement of a doctrine so startling as if there were something atrocious in proposing to liberate those who were unfortunate enough to be insane; and for years after the restraint was actually abolished, the non-restraint system was [still] called 'utopian' and impracticable" [90] (Figure 7). 


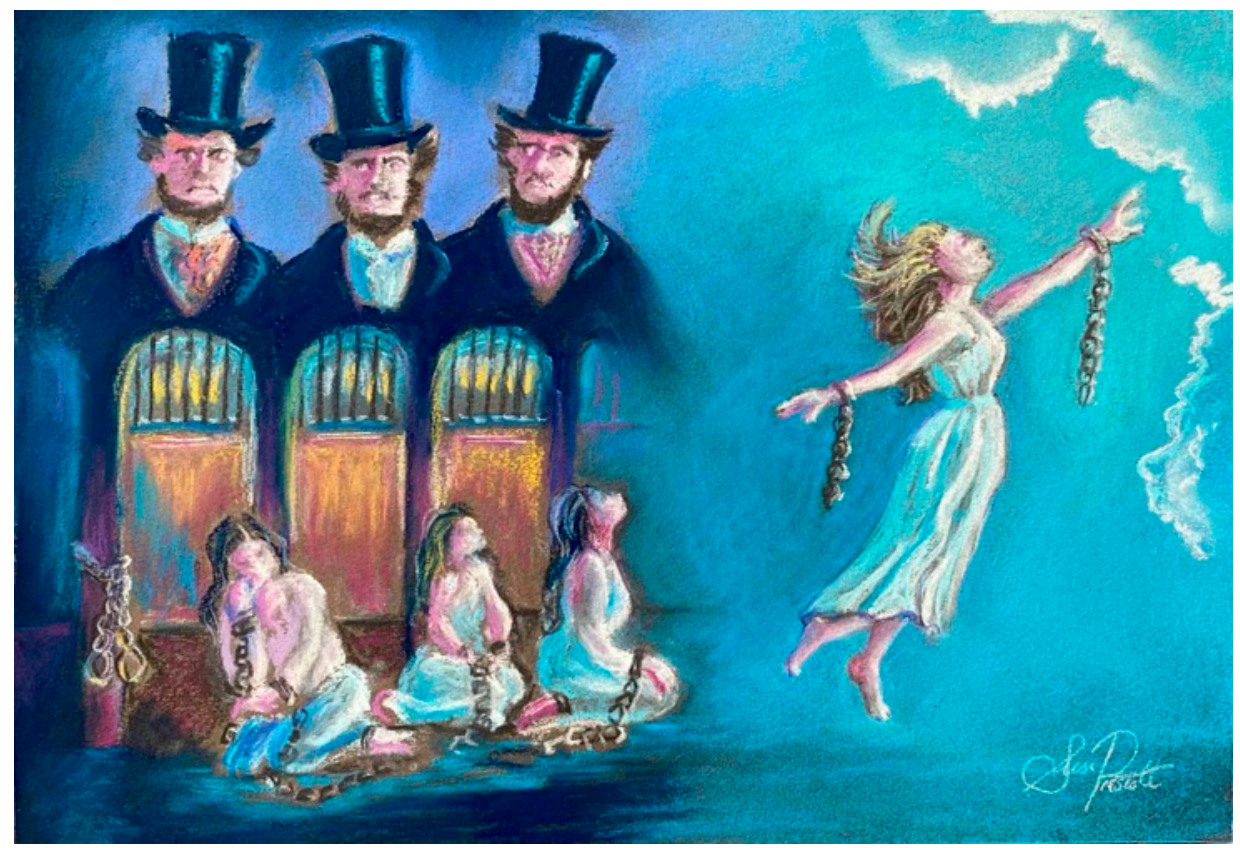

Figure 7. 19th Century humanitarians condemned and maligned. Those who advocated against physically restraining the mentally ill (many of them women, who may not have even had mental illness) were ridiculed as naïve 'utopians'. Fortunately, their dream came to pass. Art by S.L.P.

There is little doubt that these 19th century physicians used imagination and symbolic construction to transform the environment (which is to say, "world") of their patients, a step closer to utopia compared to previous conditions; yet if they were still alive, we feel confident that these same physician "utopians" would be appalled at the current status quo which allows "developed" nations to use prisons as their primary mental health institutions [91].

By the same token, Martin Luther King's inspirational speeches and the critical activism of the civil rights movement produced large scale change, but as recent events in the United States have demonstrated, not nearly enough [92,93]. The promise of the Civil Rights Act of 1964 remains unfulfilled in countless ways, and racism continues to permeate social structures with lethal consequences-the very antithesis of health promotion at scales of person, place and planet [94]. Discussing the spring 2020 protests against racial injustice and inequality, Professor Cornel West said that "you could see Martin [Luther King] right there in Atlanta, saying 'I told you about militarism, I told you about poverty, I told you about materialism, I told you about racism in all of its forms'"[95].

Thus, we can see from this example that while utopia does not exist, utopian thinking challenges the existing status quo, then transforms (or challenges) the social-political-economic structures and organizations that otherwise maintain the current reality [96]; the functional models proposed in utopian thinking may, or may not, work, but utopias are about changing, not replicating ongoing modes of social systems [97]. As asserted by philosopher Ernst Bloch, "all freedom movements are guided by utopian aspirations" [98].

As we and others have discussed previously, cynics and anti-utopian skeptics conflate a 500-year-old piece of literature (Thomas More's book Utopia (1516) and dystopian visions), with utopian thinking as a psychological and social asset; they point to failed communes as if they are the exemplar (if not the last word) on utopian thinking (whereas they are largely a study of attempts to drop out of society, often coincident with the emergence of cultic leaders); they elide the word 'thinking', and instead refer to utopian "schemes". In short, the anti-utopian misses the potential value of utopian thinking as a method to help fulfill the aims of personal, public and planetary health $[97,99]$. Since utopian thinking is oft-conflated with Utopia, More's centuries-old text, and needlessly paired 
with dystopia —an imagined state or society in which there is great suffering or injustice-a few words about the latter seem in order.

Dystopia from its Latin root means "bad or ill place"; imagining an ill place is beneficial if only because it allows us to visualize the type of world we do not want to live in. Given the unprecedented challenges of Anthropocene Syndrome, most especially the numbing loss of biodiversity and grotesque socioeconomic inequalities, scholars have pointed out that our current predicament could be described as a dystopia [41]. Moreover, it is interesting to ponder that George Orwell's dystopian novel 1984-where war is peace, freedom is imprisonment and ignorance is strength - is now taken to be a book about utopia! It seems to suggest that today's "newspeak" has succeeded in turning the word utopia on its head, suppressing utopian thinking [100].

\section{Social Dominance Orientation (SDO), Authoritarianism and the Status Quo}

Obviously, vested (powerful) interests can hijack the human desire for a 'better' world. They market their visions through the prism of fear and pessimism, or by appealing to retrograde ideas of "good old days" that selectively ignore systemic problems and injustice [97]. The realm of planetary health needs to understand the socio-political mechanisms by which such hijacking of hope operates, for it is a blockade to health at every scale $[101,102]$. To that aim, study of the allure of confidence men and cultic leaders (including those who might leverage awe through nefarious mechanisms [29]), as well as collective narcissism, may be informative [103-105].

In the planetary health context, research into authoritarianism and the related personality construct of social dominance orientation (SDO) is essential. SDO is characterized by attraction to hierarchy and areas of prestige found within social systems. SDO scales capture beliefs regarding the acceptability or entitlement of high-status groups to dominate other groups, and attitudes toward maintaining social and economic inequality. Higher scores on SDO scales are associated with lower empathy, and less concern for matters of social justice and inequalities $[80,106]$. As we will discuss below, SDO is positively correlated with system justification - the propensity to defend the status quo, even when it is ultimately against one's long-term interest to do so. At the same time, SDO may be a hallmark of certain individuals and groups that insert themselves into out-group/disadvantaged movements as "allies" [107].

Scholars have noted that advantaged (which is to say, powerful) groups might signal allyship with the disadvantaged and marginalized while "maintaining a strong focus on the needs and interests of their own advantaged group. Thus, they may seek actions that benefit the disadvantaged group on the condition that the status of their own group is maintained. Alternatively, and more malevolently, they could engage in actions which on the surface appear to support the disadvantaged group, but in reality seek to bolster the status of the advantaged group" [107].

Appreciation of SDO can inform on the ways in which an unhealthy status quo is maintained. It can help us understand why individuals and groups, such as those who fought to reform mental asylums and the organizers of the inaugural Earth Day, for example, were ridiculed as "utopians". By its very nature, utopian thinking would be unsettling to those who are resistant to change-that is, "the upholders of the old system" as asylum reformer Dr Conolly called them. Hence, there is a motivation to mock utopian thought, and maintain the myth that its precursor, imagination, is a fluffy science not to be taken seriously. In any case, as stated by scholars Moos and Brownstein, "all utopias imply criticism of the established order...thus, to those who are defenders of the status quo, the drive to utopia is an act of heresy" [96].

\section{Utopian Thinking, Recent Findings}

Thirty-five years ago, psychologist Dennis R. Fox wrote: “utopian speculation on the part of social scientists would enhance the possibility of seeking, and perhaps finding, more effective solutions to complex problems. Without the goal of a synergistic ecological utopia, we are likely to continue floundering ... keeping utopia in mind can prevent our settling for minor reforms when more 
significant change might be possible" [108]. Yet, Dr. Fox wrote at a time when anti-utopian sentiment was high. To dare to dream of utopia was considered idyll speculation, escapism, or worse, should some of that dreaming be realized, an inevitable path toward oppression and tyranny. As historian Russell Jacoby, lamenting the loss of utopian imagination, wrote: "a utopian spirit-a sense that the future could transcend the present-has vanished. Someone who believes in utopias is widely considered out to lunch, or out to kill" [109], and that "utopia has lost its ties with alluring visions of harmony and has turned into a threat" [110]

Jacoby and others have argued that the grand challenges facing humanity demand imagination, the very asset that has otherwise been stifled. Today, thanks in part to the work of Dr. Julian Fernando and colleagues, a research-based approach to utopian thinking has helped provide a point of entry for much-needed discourse. Although the research described below is preliminary, it sets up a larger framework through which we might start to assess the question "what kind of world do we want to live in?" and reinvigorate the imagination inspired by Earthrise.

First, Fernando and colleagues asked subjects to imagine and write about their own utopia; after this priming, the participants (relative to control) reported a greater desire to take action to change their current society. Moreover, utopian thinking initiated what theorists have long suspected-it activated criticism and reduced system-justifying attitudes [111]. System-justification is the conscious and non-conscious tendency to defend, bolster and justify aspects of existing social, economic and political systems. Since engaging in system justification serves the palliative function of increasing satisfaction with the status quo [112], it is easy to see how it might be a barrier to imaginative solutions in our race to cure Anthropocene Syndrome. Unsurprisingly, anti-utopianism (the degree to which people think it is "dangerous" to think about utopia) is positively correlated with system justification [111].

Next, Fernando and colleagues explored prominent themes within utopian thinking-scientific and ecological utopias. The former centers around what the researchers describe as a 'Sci-Fi' utopia where material abundance is advanced by science and technology. The Sci-Fi utopia is exemplified by Star-Trek-like visions, complete with abundant energy supplies to provide for material wealth and abundance (Figure 8). Space travel, robots and artificial intelligence are oft-imagined as part of the Sci-Fi utopia. In contrast, the ecological utopias, referred to as "Green" utopia, centers around moderation in material abundance-yet no person is in poverty-and instead seeks abundance in other forms, including life in harmony with a thriving natural environment [113].

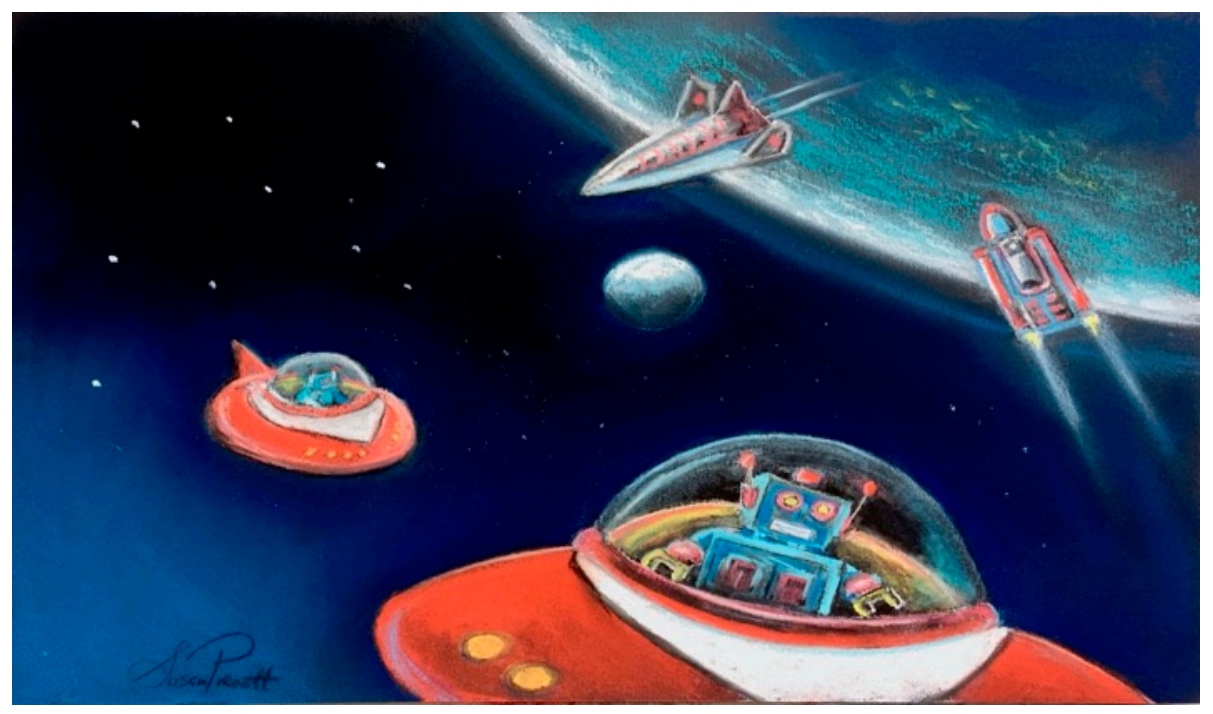

Figure 8. Technology "Sci-fi" Utopian Themes. These themes have a technocratic focus on advanced science and technology, resources for material abundance and a perceived trajectory away from societal warmth. Driven by "experts", there is little perceived role for "ordinary" people, and little motivation for social change (even when perceived positively). Artwork by S.L.P. 
When the researchers asked subjects to imagine a Green or Sci-Fi utopia, several important differences were noted. The Green utopia was rated as warmer and more socially progressive (that is, more equitable, peaceful, democratic, fair and free). Those who had positive responses to Green utopia expressed greater social change motivation, environmental striving and pro-environmental behavior. In contrast, the Sci-Fi utopia was associated with low motivation, even when it was positively evaluated. Finally, the Green utopia was shown to elicit greater perceptions of participative efficacy (that is, the feeling that their actions can "make a difference" in achieving the imagined outcomes), which in turn predicted the increase in social change motivation [113].

Green utopian thinking, according to Fernando, et al. is not anti-technology or anti-science. On the contrary, Green utopian thinking often involves technological solutions to environmental challenges. The distinction between Green vs. Sci-Fi utopia is not a "back to nature/Luddite view" vs. a "terraform Mars as soon as possible" vision. Rather, the modern ecological Green utopia embraces ideals of sufficiency, while the technocratic Sci-Fi utopia maintains ideals of material abundance [13]. However, the Green utopia as described by Fernando, et al. is not dominated by technology; for further exploration of technological utopianism, its oversell and unintended consequences, the reader is directed to the work of Carolyn Marvin, Howard P. Segal, and others [114-116]. It should be pointed out that the work of Fernando, et al. is relatively new and will need to be replicated; the likelihood that individuals within and across cultures maintain elements of both Green and Sci-Fi utopia remains high.

Although sparse, the available research suggests that individuals are more motivated to support imagined changes to society if they are directed toward a society in which people are more benevolent-affectionate, cooperative relations guided by adherence to ethics and important social values [117]. Moreover, across cultures, the idealized society of ordinary people appears to be that of moderate material abundance, and not fantastical stereotypes of utopia as decadence and material excess $[88,118]$. Although utopian thinking is likely to be colored by individual political ideology, we suspect that there are commonalities in utopian thinking that are universal throughout humanity. Obviously, bridging the gap between ideation and implementation in the context of planetary health is exceedingly complicated; it involves a democratic span over the top of treacherous political waters, an industrial-media-marketing complex with vortexes of entrenched power relations, and cultish groups that reinforce the notion that failure to "keep up" or "stay healthy" in the accelerated modern world is the fault of the individual $[119,120]$. However, in an era marked by political polarization [14,121] and generalized incivility [122,123], identifying areas of convergence on what a "good society" might look like, seems essential [124].

\section{Looking Back, Moving Forward}

The emerging body of research on utopian thinking often refers to ordinary people, and how they envision a better society [59]. This is salient, for in this context ordinary means that these individuals canvassed in studies are not political operatives, policy makers, professional philosophers and so on. Utopian thinking is a widespread phenomenon and may indeed be therapeutic to the degree that it maintains hope and optimism in the face of vast challenges. We wonder to what extent planetary health might benefit by recording the utopian thinking of ordinary people. In what ways can individual utopian thinking put into action-for example, one 'utopian' in a suburban community installs solar panels [125] - lead to a positive contagion on larger scales?

In 1988, OMNI magazine, a well-circulated publication that included research-based articles on science and medicine (mixed in with separate contributions from well-known science-fiction and fantasy writers) asked "more than two dozen citizens of the world to share with us their personal blueprints for utopia" [126]. While OMNI did make an effort to provide diversity, the common thread among the respondents was that they were highly-recognizable public figures. Nevertheless, the exercise that OMNI started was worthwhile; content analysis of the responses shows that it deserves follow-up with a more diverse set of ordinary "citizens of the world". 
The origins of OMNI's quest to extract the utopian thoughts of public figures belong to Murray Cox (1946-1994). Sitting in The Duplex piano bar in Greenwich Village, a friend leaned in and asked Cox "How come no one talks about utopia anymore?" to which the journalist did not have a satisfactory answer, other than to say, "maybe we're just selfish. It's the Eighties, a greedy era: BMWs, youth creams, second homes, the right number of kids. We're a satisfied bunch". Cox began a year-long quest, compiling the utopian thoughts of notable people. His primary concern at the outset was that "we'd get abstract, heady stuff-everyone trying to make themselves look good, all sounding the same". But that is not what happened. "After I received the first five transcripts, I knew we had something. People were serious, yes, but they were letting themselves go" [127].

Cox quickly learned that by asking individuals to describe personal blueprints for utopia, he succeeded in unmasking deeper drives and motivations found within individuals: "To learn people's ideas of utopia is to find out a great deal about them: their highest hopes and wildest dreams; their standards and prejudices" [127]. Several fell into the trap of describing dystopia, rather than utopia ('I would like to shoot any human being that sells dope to a person under the age of eighteen', wrote one). Only a few engaged in escapism and spoke of riches, wealth accumulation combined with lower taxes, Disneyland and designer bags. Generally, though, content analysis reveals remarkably consistent themes within the kind of world the respondents imagined. Coretta Scott King advanced her husband's prior art:

In his famous 1963 'I Have a Dream' speech, my husband, Martin Luther King, Jr., awakened the slumbering conscience of America with his magnificent dream of justice, equality, and brotherhood of all people. As we move toward the new millennium, we must advocate a bold new vision of a world... where valuable resources are no longer squandered on the instruments of death, but are creatively harnessed for economic development and opportunity. In this beloved community racism and sexism have been consigned to the refuse heaps of history, and every child of Earth is well nourished, well educated, and well loved. There is no ruthless exploitation of people or the environment. Freedom, human rights, and dignity, are honored under all flags, and all people are free from the bondage of hatred.

Equity, fairness, justice, educational opportunities, peace, the cure of mental illnesses, reduction in hunger, promotion of science and the arts, ecological protection, encouragement of creativity and love of nature were dominant themes in the OMNI exercise. In his response, Jonas Salk envisioned utopia as a place where a greater understanding of the human mind would lead to "insight, foresight and creativity"; through the expansion of such wisdom, we would not be taken in by the "greedy in positions of power", he said. Instead, we would use the insight, foresight and creativity to choose the right architects for a better future. For some, including the architect of the project, Cox, the challenge of describing utopia reminded them that their own previous engagement in mass movements (civil rights marches, for example) was the experience of utopian moments. Jose Miguez-Bonino, vice president of the World Council of Churches, described his experience during the swell of Argentinean human rights marches: "In these moments we are admitted into the presence of Utopia, and the memory of such 'visits' nourishes hope and gives strength to the quest."

Steve Wozniak, the inventor of the Apple Computer, said that "in my utopia children will be taught to apply critical judgment to what they see and are told, and they'll be taught to value their own imaginations, creativity and intelligence...in my utopia adults will learn that children's dreams and fantasies may become real. I want the miraculousness of the mind to be revered."

While much has been written on the developmental origins of health and disease (DOHaD) - the ways in which early life exposures, positive and negative, influence subsequent health and disease- the $\mathrm{DOHaD}$ perspective is almost exclusively adult-to-child oriented. Wozniak's utopian thinking speaks to a different angle. What might children teach adults about life-course health at scales of person, place and planet? An OMNI-sponsored children's art project in 1986 provides a hint. OMNI invited American and Soviet schoolchildren to use paintings and drawings to imagine the future in space for the two superpowers; the results showed "utopian" images-the children depicted 
adults from both nations working in collaboration, unity and friendship. The artwork made its way to exhibit, where it was concluded that it "provides the most natural way in the world to help make a bridge between the nations-letting our children show us [adults] qualities we all have in common" and that children's "art was the most vital way to cut through some of those self-imposed walls we have here on Earth; the paper walls of bureaucracy and the imaginary walls of national borders" [128].

Perhaps it is time to expand on OMNI's late-20th-century quest and canvass utopian thoughts on a larger scale, among more diverse populations, and seek input from children-and reinvigorate the momentum following Earthrise, now fifty years ago. We may well ask how utopian thoughts-in written form or art-can expand the horizons of planetary health, and how can children inform adults on what awe looks like, and how to make "healthy" choices at scales of person, place and planet? What can children teach us about the maturing science of awe? As noted by one pioneer of the environmental movement, Rachel Carson, in 1956, "a child's world is fresh and new and beautiful, full of wonder and excitement. It is our misfortune that for most of us, that clear-eyed vision, that true instinct for what is beautiful and awe-inspiring, is dimmed and even lost before we reach adulthood...each child [should be given] a sense of wonder so indestructible that it would last throughout life, as an unfailing antidote against the boredom and disenchantments of later years, the sterile preoccupation with things that are artificial, the alienation from the sources of our strength." [129]

In troubling times, such an expedition is more important than ever, remembering the grounding knowledge and ancient wisdom that can still guide our path [130]. There will be much to learn along the way; perhaps we might find a cultural artifact, our own "Project Earthrise", along the way, something to spark the imagination so badly needed in planetary health (Figure 9).

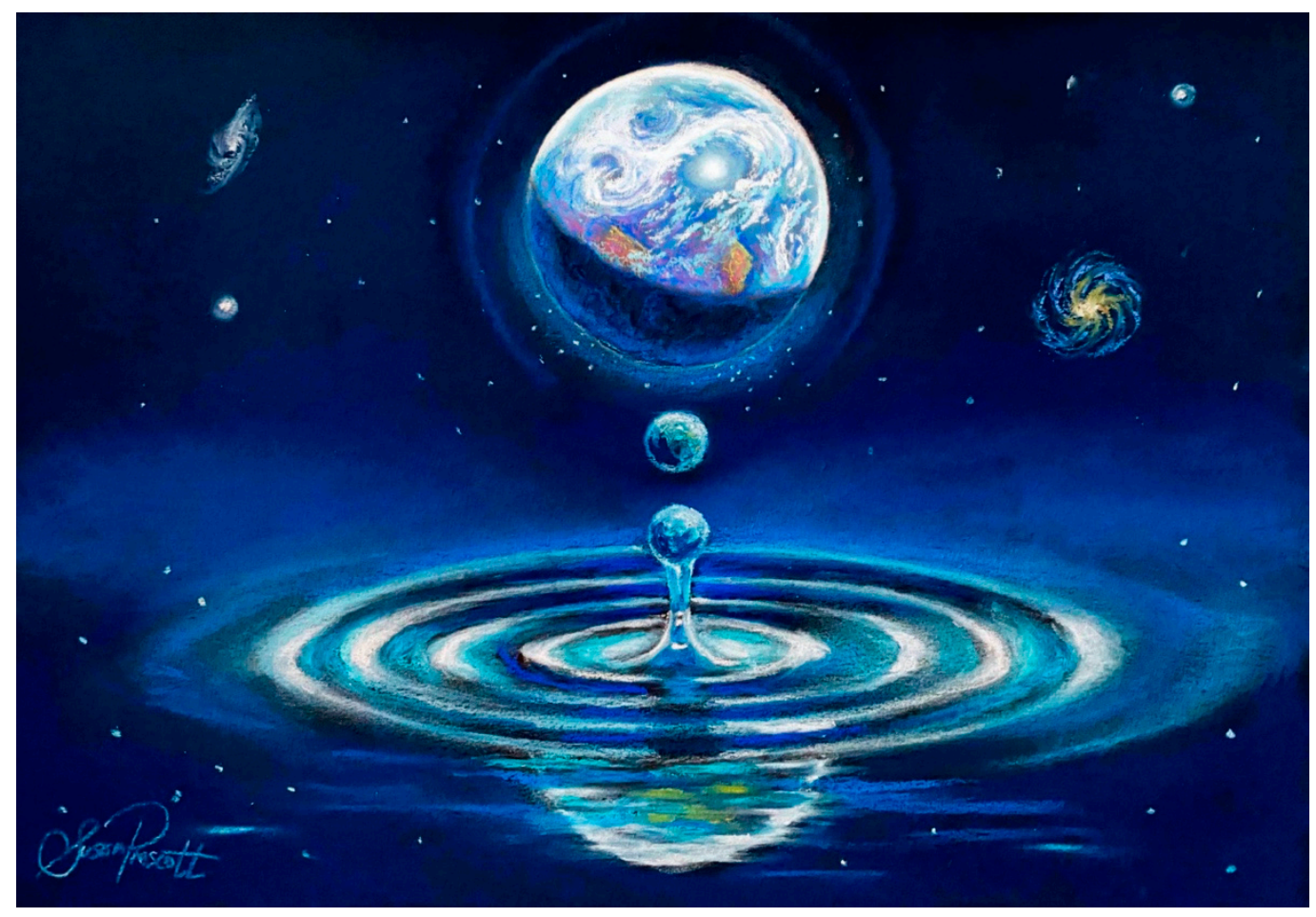

Figure 9. Project Earthrise. Creating ripples of change to bring the future into new focus through the power of imagination - it is time to imagine what kind of world we want to live in. Artwork by S.L.P.

\section{Conclusions}

"Those who believe we are talking about the Grand Canyon and the Catskills, but not Harlem and Watts, are wrong...if progress means technology that produces more kinds of things than we really want, more kinds of things than we really need, and more kinds of things than we can live with, we had better redefine progress." 
Senator Edmund S. Muskie, Inaugural Earth Day, 1970 [36]

Although planetary health is not a new idea or concept, the grand challenges of the Anthropocene have created an urgent need for multidisciplinary collaboration and a "moon-shot-like" effort directed toward solutions. As stated in the Canmore Declaration [2], planetary health requires scientific discovery and illumination of ways in which the total lived experience (mental/emotional experiences and physical/sensory exposures, both positive and negative) and environmental quality, can manifest in immune and other physiological parameters of health, disease and "dis-ease". It also requires imagination.

Truly integrated approaches require us to employ all of our assets, those ascribed to the both the "mind" and the "heart and soul" of humanity. We fully recognize that these are artificial distinctions, but our purpose is to increase the emphasis on the assets that are most needed, yet most neglected, in our current social turmoil-love, respect and kindness.

The emerging science of imagination and creativity, and exploration of utopian thinking, allows us to look back to the awe inspired by the cultural artifact known as Earthrise, and the early origins of Earth Day. We can do so with an eye toward how we might use this knowledge to lift planetary health off its plateau, not simply to prevent it from sliding into a retooled environmental health discipline, but to support the fullest potential of a movement that has been a half-century in the making. The metaphorical Doomsday Clock tells us it is past time to answer the fundamental question-what kind of world we want to live in? But first we must ask the question.

Author Contributions: Conceptualization, data curation, original draft preparation, A.C.L. and S.L.P.; review editing and project administration, S.H.B. and B.M.B. Art creations by S.L.P. All authors have read and agreed to the published version of the manuscript.

Funding: This work received no external funding.

Conflicts of Interest: The authors declare no conflict of interest.

\section{References}

1. Clash, J. Astronaut Bill Anders Recalls Famous 'Earthrise' Photo He Took from Moon. Available online: http://www.forbes.com/sites/jimclash/2015/04/17/bill-anders-recalls-famous-earthrise-photo-he-tookfrom-moon/\#7b2d29cf7223 (accessed on 16 November 2016).

2. Prescott, S.L.; Logan, A.C.; Albrecht, G.; Campbell, D.E.; Crane, J.; Cunsolo, A.; Holloway, J.W.; Kozyrskyj, A.; Lowry, C.A.; Penders, J.; et al. On Behalf of inVIVO Planetary Health, o. t. W. U. N. W., The Canmore Declaration: Statement of Principles for Planetary Health. Challenges 2018, 9, 31. [CrossRef]

3. Whitmee, S.; Haines, A.; Beyrer, C.; Boltz, F.; Capon, A.G.; de Souza Dias, B.F.; Ezeh, A.; Frumkin, H.; Gong, P.; Head, P.; et al. Safeguarding human health in the Anthropocene epoch: Report of The Rockefeller Foundation-Lancet Commission on planetary health. Lancet 2015, 386, 1973-2028. [CrossRef]

4. Logan, A.C.; Prescott, S.L.; Haahtela, T.; Katz, D.L. The importance of the exposome and allostatic load in the planetary health paradigm. J. Physiol. Anthr. 2018, 37, 15. [CrossRef] [PubMed]

5. Prescott, S.L.; Logan, A.C. Planetary Health: From the Wellspring of Holistic Medicine to Personal and Public Health Imperative. Explore 2019, 15, 98-106. [CrossRef]

6. Nelson, D.H.; Prescott, S.L.; Logan, A.C.; Bland, J.S. Clinical Ecology-Transforming 21st-Century Medicine with Planetary Health in Mind. Challenges 2019, 10, 15. [CrossRef]

7. Sargent, F. Man-environment-problems for public health. Am. J. Public Health 1972, 62, 628-633. [CrossRef] [PubMed]

8. Poole, R. Earthrise: How Man First Saw the Earth; Yale University Press: New Haven, CT, USA, 2008.

9. Maher, N.M. Apollo in the Age of Aquarius; Johns Hopkins University Press: Charles Village, MD, USA, 2017.

10. Ella Bahaire Decisive Moments: The Photographs that Made History. How Photography Became a Force to be Reckoned with in the 1960s. Available online: https://www.youtube.com/watch?v=rp8zeLNGeYw (accessed on 25 May 2020).

11. Horton, R. Offline: Planetary health-worth everything. Lancet 2018, 391, 2307. [CrossRef]

12. Dubos, R. Man Overadapting. Psychol. Today 1971, 4, 5-53. 
13. Fernando, J.W.; O’Brien, L.V.; Judge, M.; Kashima, Y. More Than Idyll Speculation: Utopian Thinking for Planetary Health. Challenges 2019, 10, 16. [CrossRef]

14. Twenge, J.M.; Honeycutt, N.; Prislin, R.; Sherman, R.A. More Polarized but More Independent: Political Party Identification and Ideological Self-Categorization Among U.S. Adults, College Students, and Late Adolescents, 1970-2015. Pers. Soc. Psychol. Bull. 2016, 42, 1364-1383. [CrossRef]

15. Donovan, R.J. Afterglow lights problems: Moon voyage turns men's thoughts inward. Los Angeles Times $1968,88,1$.

16. Apollo Imagery. NASA Image AS08-14-2383. 1968. Available online: https:/spaceflight.nasa.gov/gallery/ images/apollo/apollo8/html/as08-14-2383.html (accessed on 3 September 2020).

17. Thomas, L. The Lives of a Cell; Penguin Books: New York, NY, USA, 1974.

18. Chaikin, A. A Man on the Moon: The Voyages of the Apollo Astronauts; Penguin Publishing: New York, NY, USA, 1995.

19. Borman, F. Countdown: An. Autobiography; William Morrow and Co.: New York, NY, USA, 1988.

20. Asimov, I. The Moon could answer the riddle of life. New York Times Magazine, 13 July 1969; 12-26.

21. Clarke, A. That great Moon boom. Calgary Herald, 21 July 1969; 9.

22. Probandt, D.; Eickhorst, T.; Ellrott, A.; Amann, R.; Knittel, K. Microbial life on a sand grain: From bulk sediment to single grains. ISME J. 2018, 12, 623-633. [CrossRef] [PubMed]

23. Cavicchioli, R.; Ripple, W.J.; Timmis, K.N.; Azam, F.; Bakken, L.R.; Baylis, M.; Behrenfeld, M.J.; Boetius, A.; Boyd, P.W.; Classen, A.T.; et al. Scientists' warning to humanity: Microorganisms and climate change. Nat. Rev. Microbiol. 2019, 17, 569-586. [CrossRef] [PubMed]

24. Schabecoff, P. Mob surges, waits, stare at Expo fair. The Spokesman-Review, 16 March 1970; 2.

25. Sandler, M.W. Apollo 8: The Mission that Changed Everything; Candlewick Press: Somerville, MA, USA, 2018.

26. Spier, F. On the social impact of the Apollo 8 Earthrise photo, or the lack of it? J. Big Hist. 2019, 3, 157-189. [CrossRef]

27. The Last Whole Earth Catalog; Pertola Institute Publishing: Menlo Park, CA, USA, 1971; p. 3.

28. Ishizu, T.; Zeki, S. A neurobiological enquiry into the origins of our experience of the sublime and beautiful. Front. Hum. Neurosci. 2014, 8, 891. [CrossRef]

29. Paulson, S.; Sideris, L.; Stellar, J.; Valdesolo, P. Beyond oneself: The ethics and psychology of awe. Ann. N. Y. Acad. Sci. 2020. [CrossRef]

30. Rudd, M.; Vohs, K.D.; Aaker, J. Awe Expands People's Perception of Time, Alters Decision Making, and Enhances Well-Being. Psychol. Sci. 2012, 23, 1130-1136. [CrossRef]

31. Shiota, M.N.; Keltner, D.; Mossman, A. The nature of awe: Elicitors, appraisals, and effects on self-concept. Cogn. Emot. 2007, 21, 944-963. [CrossRef]

32. Van Cappellen, P.; Saroglou, V. Awe activates religious and spiritual feelings and behavioral intentions. Psychol. Relig. Spiritual. 2012, 4, 223-236. [CrossRef]

33. Banker, C.C.; Leary, M.R. Hypo-Egoic Nonentitlement as a Feature of Humility. Pers. Soc. Psychol. B 2020, 46, 738-753. [CrossRef]

34. Stellar, J.E.; Gordon, A.; Anderson, C.L.; Piff, P.K.; McNeil, G.D.; Keltner, D. Awe and Humility. J. Pers. Soc. Psychol. 2018, 114, 258-269. [CrossRef] [PubMed]

35. Anonymous. Earth Day for Australia. The Sydney Morning Herald, 21 August 1970; 4.

36. Cotton, S. Earth Day-The Beginning; Arno Press: New York, NY, USA, 1970.

37. Associated Press. Coordinator of Earth Day not radical in appearance. Oshkosh Northwestern, 22 April $1970 ; 21$.

38. Vonnegut, K. Excelsior! We are going to the moon! Excelsior! New York Times Magazine, 13 July $1969 ;$ 9-11.

39. Borman, F. It was desolate, so uninviting. The Sydney Morning Herald, 14 January 1969; 10.

40. Painton, P. Greening from the roots up. Time 1990, 135, 76-77.

41. Webb, G. "Occupying” our social imagination: The necessity of utopian discourses in an anti-utopian age. Perspect Glob. Dev. Technol. 2013, 12, 152-161. [CrossRef]

42. Templeton, T.; Kellaway, K. These were the Days that Shook the World. Interview with James Lovell. Available online: https://www.theguardian.com/world/2008/jan/20/review.features7 (accessed on 25 May 2020).

43. Prescott, S.L.; Logan, A.C. Down to Earth: Planetary Health and Biophilosophy in the Symbiocene Epoch. Challenges 2017, 8, 19. [CrossRef] 
44. Benatar, S.; Upshur, R.; Gill, S. Understanding the relationship between ethics, neoliberalism and power as a step towards improving the health of people and our planet. Anthr. Rev. 2018, in press. [CrossRef]

45. Mooney, G. Neoliberalism is bad for our health. Int. J. Health Serv. 2012, 42, 383-401. [CrossRef]

46. Patel, J.A.; Nielsen, F.B.H.; Badiani, A.A.; Assi, S.; Unadkat, V.; Patel, B.; Ravindrane, R.; Wardle, H. Poverty, Inequality \& COVID-19: The Forgotten Vulnerable. Public Health 2020, 183, 110-111.

47. Prescott, S.L.; Wegienka, G.; Logan, A.C.; Katz, D.L. Dysbiotic drift and biopsychosocial medicine: How the microbiome links personal, public and planetary health. Biopsychosoc. Med. 2018, 12, 7. [CrossRef]

48. Palaiodimos, L.; Kokkinidis, D.G.; Li, W.; Karamanis, D.; Ognibene, J.; Arora, S.; Southern, W.N.; Mantzoros, C.S. Severe obesity, increasing age and male sex are independently associated with worse in-hospital outcomes, and higher in-hospital mortality, in a cohort of patients with COVID-19 in the Bronx, New York. Metabolism 2020, 108, 154262. [CrossRef] [PubMed]

49. Kirby, T. Evidence mounts on the disproportionate effect of COVID-19 on ethnic minorities. Lancet Respir Med. 2020, 8, 547-548. [CrossRef]

50. Feldman, C.H.; Ramsey-Goldman, R. Widening Disparities Among Patients with Rheumatic Diseases in the COVID-19 Era: An Urgent Call to Action. Arthritis Rheumatol. 2020. [CrossRef] [PubMed]

51. Anonymous. Conservation Society Notes: Health Care. Alternatives 1980, 9, 2.

52. Stoler, P. A conversation with Jonas Salk. Psychol. Today 1983, 5, 50-56.

53. Zittoun, T.; Gillespie, A. Imagining the Collective Future: A Sociocultural Perspective. In Imagining Collective Futures. Palgrave Studies in Creativity and Culture; de Saint-Laurent, C., Obradović, S., Carriere, K., Eds.; Palgrave Macmillan: Cham, Switzerland; London, UK, 2018.

54. Franken, R.E. Human Motivation; Brooks-Cole Publishing Co.: Pacific Grove, CA, USA, 1994.

55. Richards, R. Everyday Creativity and New Views of Human Nature: Psychological, Social, and Spiritual Perspectives; American Psychological Association: Washington, DC, USA, 2007.

56. Sternberg, R.J.; Kaufman, J.C. The Nature of Human Creativity; Cambridge University Press: Cambridge, UK, 2018.

57. Hawlina, H.; Pedersen, O.C.; Zittoun, T. Imagination and social movements. Curr. Opin. Psychol. 2020, 35, 31-35. [CrossRef]

58. Marková, I.F. From imagination to well-controlled images: Challenge for the dialogical mind. In Handbook of Imagination and Culture; Zittoun, T., Glăveanu, V.P., Eds.; Oxford University Press: Oxford, NY, USA, 2017; pp. 315-349.

59. Badaan, V.; Jost, J.T.; Fernando, J.; Kashima, Y. Imagining better societies: A social psychological framework for the study of utopian thinking and collective action. Soc. Pers. Psychol. 2020, 14, 4. [CrossRef]

60. Amabile, T.M. A model of creativity and innovation in organizations. In Research in Organizational Behavior, Vol. 10:123-167; Staw, B.M., Cummings, L.L., Eds.; JAI Press: Greenwich, Philippines, 1988.

61. Whitney, W.D. The Century Dictionary and Cyclopedia. Volume IV; The Century Company: New York, NY, USA, 1906; pp. 3107-3108.

62. Hulme, M. Why we disagree about climate change. In the Hartwell Approach to Climate Policy; Rayner, S., Caine, M., Eds.; Routledge: Oxon, UK, 2015; pp. 239-243.

63. Plucker, J.A.; Beghetto, R.A.; Dow, G.T. Why isn't creativity more important to educational psychologists? Potentials, pitfalls, and future directions in creativity research. Educ. Psychol. 2004, 39, 83-96. [CrossRef]

64. Daker, R.J.; Cortes, R.A.; Lyons, I.M.; Green, A.E. Creativity Anxiety: Evidence for Anxiety That Is Specific to Creative Thinking, From STEM to the Arts. J. Exp. Psychol. Gen. 2020, 149, 42-57. [CrossRef]

65. Leopold, C.; Mayer, R.E.; Dutke, S. The Power of Imagination and Perspective in Learning From Science Text. J. Educ. Psychol. 2019, 111, 793-808. [CrossRef]

66. Baas, M.; Nevicka, B.; Ten Velden, F.S. When paying attention pays off: The mindfulness skill act with awareness promotes creative idea generation in groups. Eur. J. Work Organ. Psy. 2020. [CrossRef]

67. Berkovich-Ohana, A.; Glicksohn, J.; Ben-Soussan, T.D.; Goldstein, A. Creativity Is Enhanced by Long-Term Mindfulness Training and Is Negatively Correlated with Trait Default-Mode-Related Low-Gamma Inter-Hemispheric Connectivity. Mindfulness 2017, 8, 717-727. [CrossRef]

68. Langley, S. Facilitating Positive Emotions for Greater Creativity and Innovation. In Individual, Relational, and Contextual Dynamics of Emotions (Research on Emotion in Organizations); Petitta, L., Ed.; Emerald Publishing Limited: Melbourne, Australia, 2018; Volume 14, pp. 259-270. 
69. Sordia, N.; Martskvishvili, K.; Neubauer, A. From Creative Potential to Creative Achievements. Swiss J. Psychol. 2019, 78, 115-123. [CrossRef]

70. Di Fabio, A.; Palazzeschi, L.; Bucci, O.; Guazzini, A.; Burgassi, C.; Pesce, E. Personality Traits and Positive Resources of Workers for Sustainable Development: Is Emotional Intelligence a Mediator for Optimism and Hope? Sustainability 2018, 10, 3422. [CrossRef]

71. Gerofsky, P.R. The Relationship between Nature Relatedness, Trait Emotional Intelligence and Well-Being; The University of Western Ontario: London, ON, Canada, 2016.

72. Fido, D.; Richardson, M. Empathy mediates the relationship between nature connectedness and both callous and uncaring traits. Ecopsychology 2019, 11, 130-137. [CrossRef]

73. Marzluff, J.M. Bridging the empathy gap for invertebrates. Anim. Sentience 2020, 29, 22.

74. Atchley, R.A.; Strayer, D.L.; Atchley, P. Creativity in the wild: Improving creative reasoning through immersion in natural settings. PLoS ONE 2012, 7, e51474. [CrossRef]

75. Salk, J.E. Biology in the future. Perspect. Biol. Med. 1962, 5, 423-431. [CrossRef]

76. Scarr, L. Dr. Salk: Book deals with man's relation, not medicine. Courier-Post, 15 November 1972; 61.

77. Maute, M.F.; Locander, W.B. Innovation as a Sociopolitical Process-An Empirical-Analysis of Influence Behavior among New Product Managers. J. Bus. Res. 1994, 30, 161-174. [CrossRef]

78. Janssen, O.; van de Vliert, E.; West, M. The bright and dark sides of individual and group innovation: A Special Issue introduction. J. Organ. Behav. 2004, 25, 129-145. [CrossRef]

79. Baer, M. Putting Creativity to Work: The Implementation of Creative Ideas in Organizations. Acad. Manag. J. 2012, 55, 1102-1119. [CrossRef]

80. Prescott, S.L.; Logan, A.C.; Katz, D.L. Preventive Medicine for Person, Place, and Planet: Revisiting the Concept of High-Level Wellness in the Planetary Health Paradigm. Int. J. Env. Res. Pub. Health 2019, 16, 238. [CrossRef]

81. Redvers, N.; Yellow Bird, M.; Quinn, D.; Yunkaporta, T.; Arabena, K. Molecular Decolonization: An Indigenous Microcosm Perspective of Planetary Health. Int. J. Env. Res. Public Health 2020, 17, 4586. [CrossRef] [PubMed]

82. Branas, C.C.; South, E.; Kondo, M.C.; Hohl, B.C.; Bourgois, P.; Wiebe, D.J.; MacDonald, J.M. Citywide cluster randomized trial to restore blighted vacant land and its effects on violence, crime, and fear. Proc. Natl. Acad. Sci. USA 2018, 115, 2946-2951. [CrossRef] [PubMed]

83. South, E.C.; Hohl, B.C.; Kondo, M.C.; MacDonald, J.M.; Branas, C.C. Effect of Greening Vacant Land on Mental Health of Community-Dwelling Adults: A Cluster Randomized Trial. JAMA Netw. Open 2018, 1, e180298. [CrossRef] [PubMed]

84. Mills, J.G.; Bissett, A.; Gellie, N.J.C.; Lowe, A.J.; Selway, C.A.; Thomas, T.; Weinstein, P.; Weyrich, L.S.; Breed, M.F. Revegetation of urban green space rewilds soil microbiotas with implications for human health and urban design. Restor. Ecol. 2020, in press. [CrossRef]

85. Thompson, B.; Molina, Y.; Viswanath, K.; Warnecke, R.; Prelip, M.L. Strategies To Empower Communities To Reduce Health Disparities. Health Aff. 2016, 1424-1428, 35. [CrossRef]

86. Gardner, C.D.; Hauser, M.E. Food revolution. Am. J. Lifestyle Med. 2017, 11, 387-396. [CrossRef]

87. Bryan, C.J.; Yeager, D.S.; Hinojosa, C.P.; Chabot, A.; Bergen, H.; Kawamura, M.; Steubing, F. Harnessing adolescent values to motivate healthier eating. Proc. Natl. Acad. Sci. USA 2016, 113, 10830-10835. [CrossRef]

88. Kashima, Y.; Fernando, J. Utopia and ideology in cultural dynamics. Curr. Opin. Behav. Sci. 2020, 34, $102-106$. [CrossRef]

89. Parigot, F. On Civilization and Insanity. J. Psychol. Med. Ment. Pathol. 1857, 10, 338-358. [PubMed]

90. Conolly, J. The Construction and Government of Lunatic Asylums and Hospitals for the Insane; John Chruchill Co.: London, UK, 1847.

91. Al-Rousan, T.; Rubenstein, L.; Sieleni, B.; Deol, H.; Wallace, R.B. Inside the nation's largest mental health institution: A prevalence study in a state prison system. BMC Public Health 2017, 17, 342. [CrossRef] [PubMed]

92. Watson-Singleton, N.N.; Mekawi, Y.; Wilkins, K.V.; Jatta, I.F. Racism's Effect on Depressive Symptoms: Examining Perseverative Cognition and Black Lives Matter Activism as Moderators. J. Couns. Psychol. 2020, in press. [CrossRef] [PubMed]

93. Seaton, E.K.; Yellow Horse, A.J.; Yoo, H.C.; Vargas, E. Health Implications of Black Lives Matter Among Black Adults. J. Racial Ethn. Health Disparities 2020, 10. [CrossRef] 
94. Canady, V.A. Mental health groups unite on addressing social injustice, civil unrest. Ment. Health Wkly. 2020, 30, 1-3. [CrossRef]

95. Cornel West: On George Floyd and The 'Failed' American Experiment. Available online: https://www. youtube.com/watch?v=JNfqr-rzj5I (accessed on 12 May 2020).

96. Moos, R.; Brownstein, R. Environment and Utopia: A Synthesis; Plenum Publishing: New York, NY, USA, 1977.

97. Prescott, S.L.; Logan, A.C. Larger than Life: Injecting Hope into the Planetary Health Paradigm. Challenges 2018, 9, 13. [CrossRef]

98. Bloch, E. Principle of Hope —Volume I; Basil Blackwell Publishers: Oxford, UK, 1986.

99. Levitas, R. Less of More. Utop. Stud. 2016, 27, 395-401. [CrossRef]

100. Cornish, E. The Study of the Future. An Introduction to the art and Science of Understanding and Shaping Tomorrow's World; World Future Society Publishing: Bethesda, MD, USA, 1977.

101. McKee, M. Health professionals must uphold truth and human rights. Eur. J. Public Health 2017, $27,6-7$. [CrossRef]

102. Greer, S.L. Medicine, public health and the populist radical right. J. R. Soc. Med. 2017, 110, 305-308. [CrossRef]

103. Orbach, B.; Huang, L. Con Men and Their Enablers: The Anatomy of Confidence Games. Soc. Res. 2018, 85, 795-822.

104. Rousselet, M.; Duretete, O.; Hardouin, J.B.; Grall-Bronnec, M. Cult membership: What factors contribute to joining or leaving? Psychiatr. Res. 2017, 257, 27-33. [CrossRef] [PubMed]

105. de Zavala, A.G.; Guerra, R.; Simao, C. The Relationship between the Brexit Vote and Individual Predictors of Prejudice: Collective Narcissism, Right Wing Authoritarianism, Social Dominance Orientation. Front. Psychol. 2017, 8. [CrossRef]

106. Logan, A.C.; Prescott, S.L.; Katz, D.L. Golden Age of Medicine 2.0: Lifestyle Medicine and Planetary Health Prioritized. J. Lifestyle Med. 2019, 9, 75-91. [CrossRef] [PubMed]

107. Radke, H.R.M.; Kutlaca, M.; Siem, B.; Wright, S.C.; Becker, J.C. Beyond Allyship: Motivations for Advantaged Group Members to Engage in Action for Disadvantaged Groups. Pers. Soc. Psychol Rev. 2020. [CrossRef] [PubMed]

108. Fox, D.R. Psychology, Ideology, Utopia, and the Commons. Am. Psychol. 1985, 40, 48-58. [CrossRef]

109. Jacoby, R. The End of Utopia: Politics and Culture in an Age of Apathy; Basic Books: New York, NY, USA, 1999.

110. Jacoby, R. Picture Imperfect: Utopian Thought for an Anti-Utopian Age; Columbia University Press: New York, NY, USA, 2005.

111. Fernando, J.W.; Burden, N.; Ferguson, A.; O’Brien, L.V.; Judge, M.; Kashima, Y. Functions of Utopia: How Utopian Thinking Motivates Societal Engagement. Pers. Soc. Psychol. Bull. 2018, 44, 779-792. [CrossRef]

112. Jost, J.T. A quarter century of system justification theory: Questions, answers, criticisms, and societal applications. Br. J. Soc. Psychol. 2019, 58, 263-314. [CrossRef]

113. Fernando, J.W.; O’Brien, L.V.; Burden, N.J.; Judge, M.; Kashima, Y. Greens or space invaders: Prominent utopian themes and effects on social change motivation. Eur. J. Soc. Psychol. 2020, 50, 278-291. [CrossRef]

114. Marvin, C. When Old Technologies were New; Oxford University Press: Oxford, UK, 1988.

115. Segal, H.P. Technological Utopianism in American Culture; University of Chicago Press: Chicago, IL, USA, 1985.

116. Sturken, M.; Thomas, D.; Ball-Rokeach, S.J. Technological Visions: The Hopes and Fears that Shape New Technologies; Temple University Press: Philadelphia, PA, USA, 2004.

117. Bain, P.G.; Hornsey, M.J.; Bongiorno, R.; Kashima, Y.; Crimston, D. Collective Futures: How Projections About the Future of Society Are Related to Actions and Attitudes Supporting Social Change. Pers. Soc. Psychol. B 2013, 39, 523-539. [CrossRef]

118. Hornsey, M.J.; Bain, P.G.; Harris, E.A.; Lebedeva, N.; Kashima, E.S.; Guan, Y.J.; Gonzalez, R.; Chen, S.X.; Blumen, S. How Much Is Enough in a Perfect World? Cultural Variation in Ideal Levels of Happiness, Pleasure, Freedom, Health, Self-Esteem, Longevity, and Intelligence. Psychol. Sci. 2018, 29, 1393-1404. [CrossRef]

119. Eckersley, R. Letter to the editor: Are indicators telling us the real story about progress?: Closing the Gap Between the Science and Politics of Progress: Science's Greatest Challenge. Soc. Indic. Res. 2019, 141, 919-929. [CrossRef]

120. Teasdale, S.; Roy, M.J.; Ziegler, R.; Mauksch, S.; Dey, P.; Raufflet, E.B. Everyone a Changemaker? Exploring the Moral Underpinnings of Social Innovation Discourse Through Real Utopias. J. Soc. Entrep. 2020. [CrossRef] 
121. Baldassarri, D.; Gelman, A. Partisans without Constraint: Political Polarization and Trends in American Public Opinion. Am. J. Sociol. 2008, 114, 408-446. [CrossRef] [PubMed]

122. Rosen, C.C.; Koopman, J.; Gabriel, A.S.; Johnson, R.E. Who Strikes Back? A Daily Investigation of When and Why Incivility Begets Incivility. J. Appl. Psychol. 2016, 101, 1620-1634. [CrossRef] [PubMed]

123. McCarthy, K.; Pearce, J.L.; John Morton, J.; Lyon, S. Do you pass it on? An examination of the consequences of perceived cyber incivility. Organiz. Mang. J. 2020, in press. [CrossRef]

124. Sterling, J.; Jost, J.T.; Hardin, C.D. Liberal and Conservative Representations of the Good Society: A (Social) Structural Topic Modeling Approach. Sage Open 2019, 9. [CrossRef]

125. Busic-Sontic, A.; Fuerst, F. Does your personality shape your reaction to your neighbours' behaviour? A spatial study of the diffusion of solar panels. Energy Build. 2018, 158, 1275-1285. [CrossRef]

126. Long, M. Paradise tossed. OMNI 1988, 10, 36-42.

127. Cox, M. Forum: In search of utopia. OMNI 1988, 10, 14.

128. Hooper, J. The artists of Detente. OMNI 1986, 9, 96-101.

129. Carson, R. Help your child to wonder. Woman's Home Companion 1956, 83, 24-27.

130. Redvers, N. The Value of Global Indigenous Knowledge in Planetary Health. Challenges 2018, 9, 30. [CrossRef]

(C) 2020 by the authors. Licensee MDPI, Basel, Switzerland. This article is an open access article distributed under the terms and conditions of the Creative Commons Attribution (CC BY) license (http://creativecommons.org/licenses/by/4.0/). 